Das Manuskript der Zusammenfassung zu dem Vortrag 225, Zur Häufigkeit der Transfusionshepatitis nach Herzoperationen von M. Schlaak*, A. Bernhard, K. Dunkel, H..J. Streckfuß, K. Held, P. Jipp und J. Schaefer-Kiel, wurde nicht vorgelegt.

Das Manuskript der Zusammenfassung zu dem Vortrag 226, Infeltionen bei Alloarthroplastik der Hüfte von H. Beck-Erlangen, wurde nicht vorgelegt.

\title{
227. Infektionsprophylaxe bei Hüftgelenksendoprothesen
}

\author{
H. W. BuchноLz-Hamburg
}

Prophylaxis against Infections at the Total Prosthesis of the Hip Joint

Summary. The total prosthesis of the hip joint has a special tendency to infections due to the size of the implanted material.

Measurements of antisepsis at the ward, the bed-change-zone and the operation room are discussed.

Special reference is made to the necessity of antiseptic measurements during the operation. By mixing antibiotic powder with Palacos one gets after finishing of the hardening process a reliable protection against infection in the surrounding tissue of the implanted prosthesis. By this measurement deep infection rate could be lowered from $2 \%$ to $0.2 \%$.

Zusammenfassung. Hüftgelenksendoprothesen sind wegen der Größe des Implantates in besonderem Maße infektionsanfällig. Es werden die Maßnahmen der Asepsis auf der Krankenstation, in der Umbettzone und im Operationsraum besprochen. Auf die Notwendigkeit, während der Operation besondere Maßnahmen zur Verhinderung einer Infektion zu treffen, wird hingewiesen. Durch das Untermischen eines Antibioticum unter das Palacos kann man auch nach Aushärtung einen Infektionsschutz in unmittelbarer Umgebung der eingepflanzten Endoprothese erreichen. Es gelang mit dieser Maßnahme, die tiefen Infektionen von $2 \%$ auf $0,2 \%$ zu senken.

\section{Stumpfe Herz- und Lungentraumen. Diagnostische und therapeutische Erfahrungen}

W. Bross*, T. Bross, L. Dymala, R. Koltowski, St. Koczorowski, A. Kustrzycki, B. Olejak, E. Rogalski und W. WrezLewiczWroclaw/Polen

Blunt Heart and Lung Injuries. Diagnostic and Therapeutic Experience

Summary. A clinical material of 682 thorax injuries is presented by the authors. Among these are 68 lung and bronchial injuries, 5 cardiac traumas and 10 traumatic injuries of the aorta thoracalis. The authors stress that blunt thorax traumas can cause a variety of clinical symptoms and signs, which are treated conservatively 